\title{
Spontaneous remission of adult-onset minimal change nephrotic syndrome associated with influenza B infection: a case report
}

Ayumi Haruki, Eiji Ishikawa* (D, Kan Katayama, Takayasu Ito, Takuya Hiramoto, Mika Fujimoto, Tomohiro Murata and Masaaki Ito

\begin{abstract}
Background: While the majority of adult-onset minimal change nephrotic syndrome (MCNS) is a primary or an idiopathic form of disease, it can also occur as a secondary form. Reports on the spontaneous remission of MCNS are rare since the condition is typically treated with corticosteroids. We herein describe the spontaneous remission of adult-onset MCNS in a patient who developed nephrotic syndrome after type B influenza infection.

Case presentation: A 50-year-old woman experienced fever, cough, malaise, and low back pain, which had persisted for 6 days before she presented to our hospital, and edema of the face and limbs, which had persisted for 5 days before her presentation. She was diagnosed with type B influenza infection and later exhibited an exacerbation of facial edema, decreased urine output, and a high level of proteinuria. She was referred to our department after the diagnosis of nephrotic syndrome. On admission, her proteinuria level was $20.88 \mathrm{~g} / \mathrm{gCr}$ and her selectivity index value was 0.13 . The examination of a kidney biopsy specimen obtained on the fourth day of hospitalization under a light microscope revealed minor abnormalities. An immunofluorescence showed only nonspecific granular IgM deposits in the mesangium. Electron microscopy showed extensive foot process effacement without any immune complex deposits. Based on these findings, the patient was diagnosed with MCNS. After admission, the proteinuria decreased to $0.06 \mathrm{~g} / \mathrm{gCr}$ with rest and sodium restriction ( $6 \mathrm{~g} /$ day) alone; a complete remission from nephrotic syndrome was observed at approximately 2 weeks after the onset of symptoms. There have been no signs of recurrence of nephrotic syndrome in the one years since.

Conclusion: We experienced a rare case in which spontaneous remission of MCNS occurred within a short period of 2 weeks after influenza B infection. When patients present with nephrotic syndrome after an infection, it is necessary to consider MCNS in the differential diagnosis, which also includes post-infectious glomerulonephritis and the acute exacerbation of IgA nephropathy.
\end{abstract}

Keywords: Minimal change nephrotic syndrome, Spontaneous remission, Type B influenza infection

\footnotetext{
* Correspondence: ishijin@clin.medic.mie-u.ac.jp

Department of Cardiology and Nephrology, Mie University Graduate School

of Medicine, 2-174 Edobashi, Tsu, Mie 514-8507, Japan
}

(c) The Author(s). 2018 Open Access This article is distributed under the terms of the Creative Commons Attribution 4.0 International License (http://creativecommons.org/licenses/by/4.0/), which permits unrestricted use, distribution, and reproduction in any medium, provided you give appropriate credit to the original author(s) and the source, provide a link to the Creative Commons license, and indicate if changes were made. The Creative Commons Public Domain Dedication waiver (http://creativecommons.org/publicdomain/zero/1.0/) applies to the data made available in this article, unless otherwise stated. 


\section{Background}

Minimal change nephrotic syndrome (MCNS) is known to account for $10-15 \%$ of nephrotic syndrome in adults [1]. While the majority of adult-onset MCNS is a primary or idiopathic form of disease, it can also occur as a secondary form due to infection, medication, tumor, or other kidney diseases [2]. Although spontaneous remission is known to occur in MCNS, there are few recent reports of this phenomenon because initial treatment with corticosteroids has been widely-accepted. We herein report a case of spontaneous remission of MCNS in a patient who developed nephrotic syndrome after contracting type B influenza.

\section{Case presentation}

The patient was a 50-year-old woman with a chief complaint of edema. She had previously been healthy, and previous physical examinations revealed no abnormal urinalysis results. She experienced fever, cough, malaise, and low back pain for 6 days and edema of the face and limbs for 5 days before visiting our hospital. She was diagnosed with type B influenza by a local physician 3 days prior to visiting our hospital. The patient later exhibited an exacerbation of facial edema, decreased urine output, and a high level of proteinuria. She was subsequently diagnosed with nephrotic syndrome and was referred to our department.

The physical findings on admission were as follows: height, $150.1 \mathrm{~cm}$; weight, $48.3 \mathrm{~kg}$; body mass index, 21.4; body temperature, $36.2^{\circ} \mathrm{C}$; blood pressure, $109 / 83 \mathrm{mmHg}$; and oxygen saturation on room-air, $99 \%$. In addition, the patient experienced facial edema and pitting edema of both lower legs. The laboratory findings on admission were as follows: total protein, $5.2 \mathrm{~g} / \mathrm{dL}$; albumin, $2.0 \mathrm{~g} / \mathrm{dL}$; blood urea nitrogen, $13 \mathrm{mg} / \mathrm{dL}$; creatinine, $0.84 \mathrm{mg} / \mathrm{dL}$; estimated glomerular filtration rate, $56.5 \mathrm{~mL} / \mathrm{min} / 1.73 \mathrm{~m}^{2}$; total cholesterol, $308 \mathrm{mg} / \mathrm{dL}$; immunoglobulin G (IgG), $1320 \mathrm{mg} / \mathrm{dL} ;$ IgA, $354 \mathrm{mg} / \mathrm{dL} ;$ IgM, $192 \mathrm{mg} / \mathrm{dL}$; IgE, $2966 \mathrm{IU} / \mathrm{mL}$; complement 3, $83.3 \mathrm{mg} / \mathrm{dL}$ (normal range 65-141 mg/dL); complement 4, $40.9 \mathrm{mg} / \mathrm{dL}$ (normal range $13-40 \mathrm{mg} / \mathrm{dL}$ ); and total hemolytic complement (CH50), $40.5 \mathrm{U} / \mathrm{mL}$ (normal range 31-48 U/mL). The patient was negative for hepatitis B virus surface antigen, hepatitis $C$ virus antibodies, and human immunodeficiency virus antibodies. She had previously been infected with parvovirus B19. Her proteinuria level was $20.88 \mathrm{~g} / \mathrm{gCr}$, her selectivity index value was 0.13 , and her urine sodium level was $8 \mathrm{mEq} / \mathrm{L}$. Urine sediments showed 1-4 red blood cells per high-power field without any abnormal casts. There were no notable abnormalities electrocardiography or chest X-ray images.

A kidney biopsy performed on the fourth day of hospitalization under suspicion of MCNS, IgA nephropathy, or post-streptococcal acute glomerulonephritis did not show glomerular basement membrane thickening, or endocapillary or mesangial cell proliferation (Figs. $1 \mathrm{a}$ and b). An immunofluorescence study showed nonspecific granular IgM deposits in the mesangium. Electron microscopy showed extensive foot process effacement, but immune complex deposits were not observed (Fig. 2). Based on the above findings, the patient was diagnosed with MCNS.

After admission, the patient's proteinuria decreased to $0.06 \mathrm{~g} / \mathrm{gCr}$ with rest and sodium restriction $(6 \mathrm{~g} /$ day) alone, and a complete remission from nephrotic syndrome was observed at approximately 2 weeks after the onset of symptoms. No recurrence of nephrotic syndrome was
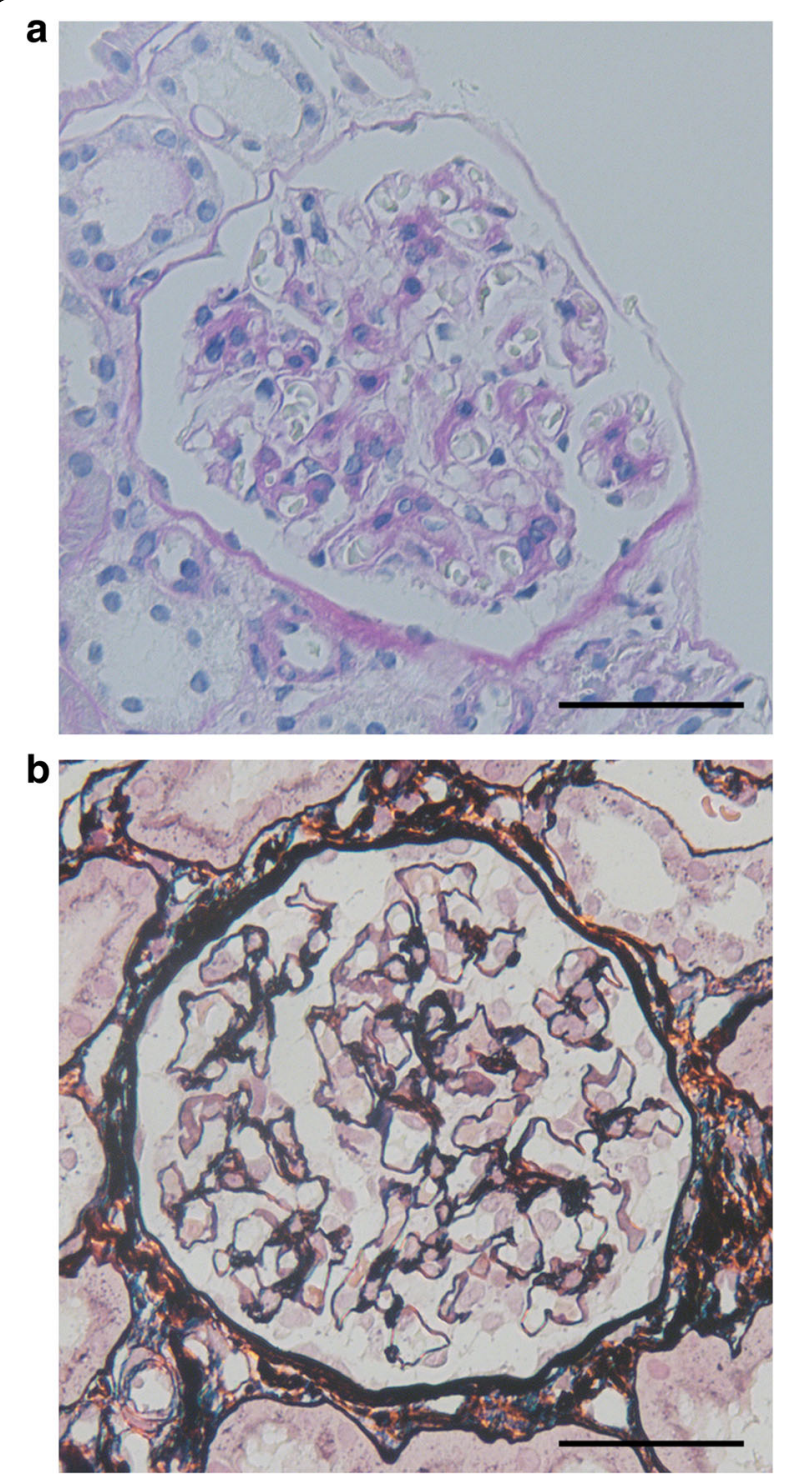

Fig. 1 The light microscopic examination of a kidney biopsy specimen. a Periodic acid-Schiff staining did not show mesangial cell proliferation or increases in mesangial matrix. b Periodic acid methenamine silver staining did not show thickening, double-contouring, or spike formation of the basement membrane. Scale bars, $50 \mu \mathrm{m}$ 


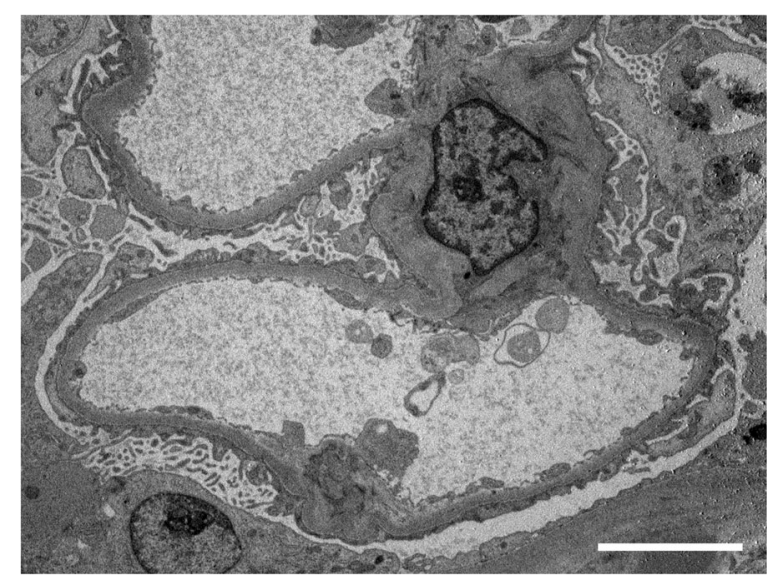

Fig. 2 The electron microscopic findings. No immune complex deposits were observed. Extensive foot process effacement was observed. Scale bar, $5 \mu \mathrm{m}$

observed at an outpatient visit one month later (Fig. 3). No recurrence has been noted in the one years since.

\section{Discussion}

In the present case, the patient developed nephrotic syndrome following an influenza B infection and was diagnosed with MCNS based on her clinical course and the results of the histopathological examination of a kidney biopsy specimen. With careful observation in our hospital, spontaneous remission occurred within two weeks after the onset of symptoms without corticosteroid treatment.

Since the etiology of nephrotic syndrome in adults is more diverse than in children, the indication for a renal biopsy differs between adults and children [3]. Typically, nephrotic syndrome in children achieve complete remission within weeks, whereas that in adults require months. Therefore, a renal biopsy is not routinely performed in children. In the present case, the patient's proteinuria was $1.59 \mathrm{~g} / \mathrm{gCr}$, and her serum albumin level was $1.8 \mathrm{~g} / \mathrm{dL}$ on the day before the renal biopsy. Although her urinary protein was improving, it was still over $1 \mathrm{~g} / \mathrm{gCr}$. It was necessary to make a differential diagnosis between MCNS and IgA nephropathy or post-streptococcal acute glomerulonephritis, which carried a risk of worsening immediately after infections. Accurately diagnosing the etiology of nephrotic syndrome strongly influences the subsequent treatment options.

The patient was diagnosed with influenza by her previous physician using a quick diagnostic kit (Quick-Navi ${ }^{\mathrm{Tm}}-\mathrm{Flu}$, Otsuka Pharmaceutical Co., Ltd., Tokyo, Japan). A serological diagnosis of the influenza antibodies was not conducted. However, this quick diagnostic kit has a specificity of $98.2 \%$ and a sensitivity of $62.3 \%$ [4], and the likelihood of a false-positive result is low when the test result is positive. Thus, together with the symptoms that the patient exhibited, it is highly likely that she was affected by influenza.

We lacked data on the proteinuria on the day of the influenza B infection diagnosis because no urinalysis was performed at the local clinic where her influenza $B$ infection was diagnosed. However, she had undergone an annual health checkup every year before the occurrence of nephrotic syndrome and had shown no proteinuria four months before the influenza B infection. She was therefore deemed to have been completely healthy shortly before developing a high fever as her first symptom of influenza $B$ infection.

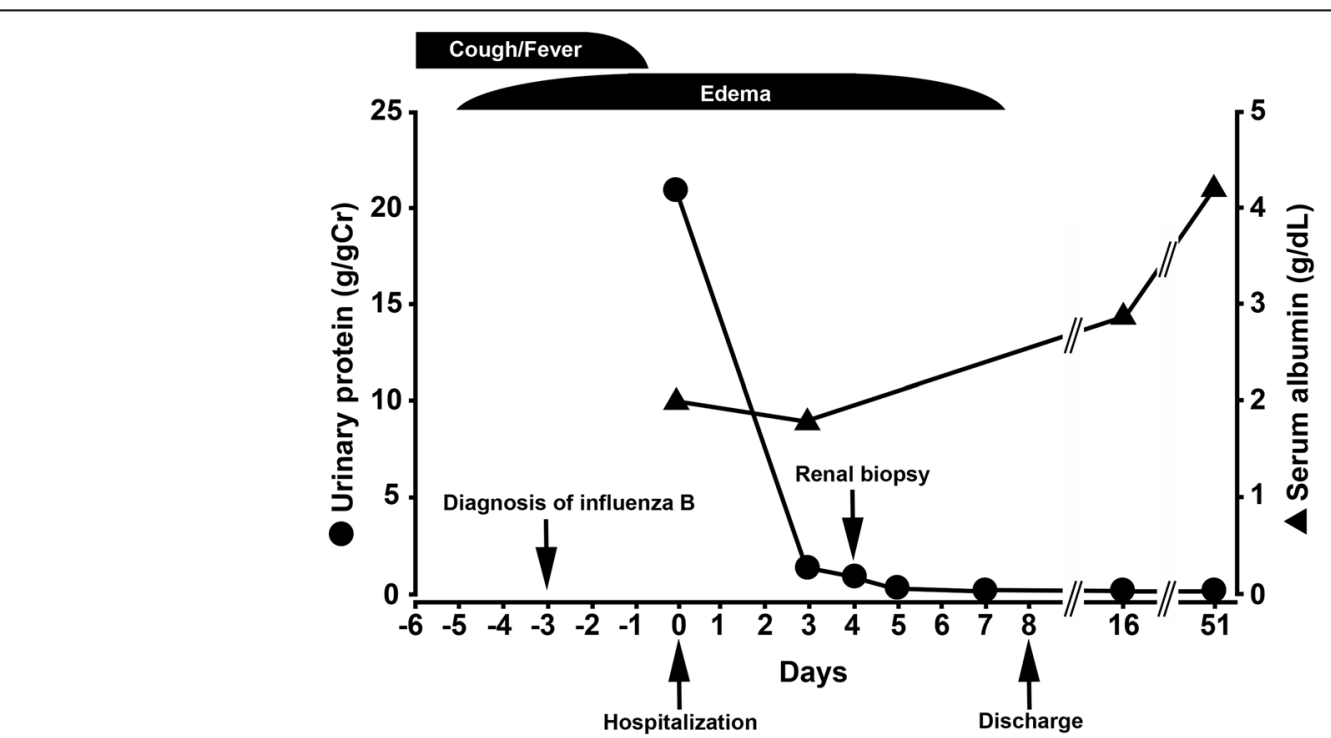

Fig. 3 The clinical course. Spontaneous remission of acute-onset generalized edema and high levels of proteinuria that occurred after influenza infection. Spontaneous remission was observed after approximately 2 weeks 
Although reports on the association between influenza infection and MCNS are extremely limited, the association between the viral infection of upper respiratory tract including influenza virus and the recurrence of childhood nephrotic syndrome has previously been reported [5]. Another article reported that MCNS recurred after a patient contracted influenza [6]. Those authors suggested the possibility of an unknown rare genetic or environmental predisposition that was essential for the pandemic influenza virus to cause podocyte damage and nephrotic syndrome [6]. A case in which MCNS developed after an influenza vaccination has also been reported [7]. Furthermore, nephrotic syndrome was reported to develop in a pediatric patient after the patient contracted influenza [8].

Among the MCNS cases in which spontaneous remission was reported, there were cases of secondary MCNS that developed after viral infections such as rubeola or varicella [9], after receiving medication [10], and after an influenza vaccination [7]. In addition, the spontaneous remission of MCNS has been reported in cases in which complications of viral infections such as measles [11], varicella [12], and hepatitis A virus [13] occurred while a patient was affected with MCNS. Although the pathogenesis of MCNS is considered to be multifactorial, attributed to both intrinsic and extrinsic factors [14], one article has suggested that T-cell dysfunction and immunologic abnormalities of permeability factors and CD80 are involved [15]. A previous report showed that the serum IgE level was high in MCNS patients compared to normal controls at the diagnosis and in remission and suggested some type of immune abnormality in MCNS patients [16]. In the present case, the serum IgE level was high at $2966 \mathrm{IU} / \mathrm{mL}$ and remain high even after remission $(527 \mathrm{IU} / \mathrm{mL})$. We hypothesized that the present case had already been predisposed to MCNS and changes in immunity due to the influenza B infection, leading to the onset of MCNS, and remission was thought to have occurred as a result of the immediate normalization of the immune system after recovery from influenza B infection.

The involvement of medications, including nonsteroidal anti-inflammatory drugs, lithium, interferon, ampicillin, rifampicin, D-penicillamine, and pamidronate, is known to cause secondary MCNS [2]. In the present case, although the patient did not take routine oral medications, other medications, including garenoxacin, Maobushisaishinto (a Chinese medicine), and acetaminophen were prescribed after she was diagnosed with influenza. Although these medications may have led to the onset of MCNS, we believe that the likelihood of that was low since the patient had exhibited edema prior to taking the prescribed medications.

The spontaneous remission of MCNS was not uncommon in the 1940s to 1950s before corticosteroids were used as the standard treatment [17]. As corticosteroids became the standard treatment for MCNS, the actual situation regarding spontaneous remission became unclear since corticosteroids are administered at a relatively early time point. Consequently, reports on the spontaneous remission of MCNS are rare. Nolasco et al. reported spontaneous remission in 6 of 89 patients with adult-onset MCNS (6.7\%) [18], and Shinzawa et al. similarly reported spontaneous remission in 9 of 142 patients (6.3\%) [19]. Spontaneous remission is also known to occur in cases in which MCNS frequently recurs: there are reports of spontaneous remission in both initial and recurrent adult-onset MCNS. Spontaneous remission occurred in $6 \%$ of 50 patients with initial MCNS, and in $33 \%$ of 51 patients with recurrent MCNS $[20,21]$. In previous reports on the spontaneous remission of MCNS, no specific trends were observed with regard to the duration until remission, age, sex, cause, and clinical findings [18-21].

\section{Conclusion}

Reports on initial MCNS after contracting influenza are rare. We experienced a case in which spontaneous remission occurred in a short period of 2 weeks. In cases of nephrotic syndrome after infection, it is necessary to consider MCNS as well as post-infectious glomerulonephritis and an acute exacerbation of IgA nephropathy in the differential diagnosis. Moreover, spontaneous remission may occur in such cases; thus, decisions concerning the administration of corticosteroids should be made carefully. The further accumulation of cases is necessary for future study.

\section{Abbreviations}

CH50: total hemolytic complement; IgG: immunoglobulin G; MCNS: minimal change nephrotic syndrome

\section{Availability of data and materials}

The datasets used and/or analysed during the current study are available from the corresponding author on reasonable request.

\section{Authors' contributions}

$\mathrm{AH}, \mathrm{El}$ and $\mathrm{KK}$ drafted the manuscript. $\mathrm{AH}, \mathrm{TI}$ and $\mathrm{TH}$ participated in the acquisition of clinical data. MF and TM carried out the histological examination of the kidney. $\mathrm{AH}, \mathrm{El}, \mathrm{KK}$ and $\mathrm{MI}$ revised a draft critically for important intellectual content. All authors read and approved the final manuscript.

Ethics approval and consent to participate Not applicable.

\section{Consent for publication}

Written informed consent was obtained from the patient for the publication of this Case report. A copy of the written consent is available for review by the editor of this journal.

\section{Competing interests}

$\mathrm{Ml}$ received departmental scholarship funds of $\geq 1,000,000$ yen per year for direct expenses from MSD K.K., Sumitomo Dainippon Pharma Co., Ltd., Daiichi Sankyo Company Limited, Pfizer Japan Inc., Astellas Pharma Inc., Otsuka Pharmaceutical Co., Ltd., and Takeda Pharmaceutical Company Limited in 2014, from MSD K.K., Bristol-Myers Squibb, BIOTORONIK JAPAN. Inc., Astellas Pharma Inc., Shionogi \& Co., Ltd., and Otsuka Pharmaceutical Co., Ltd. in 2015, and MSD K.K., Astellas Pharma Inc., Takeda Pharmaceutical Company Limited, Daiichi Sankyo Company Limited, and Otsuka 
Pharmaceutical Co., Ltd. in 2016. The companies associated with this funding were not involved in the preparation of the manuscript or the decision to publish the present case report. The other authors declare no conflicts of interest in association with the present study.

\section{Publisher's Note}

Springer Nature remains neutral with regard to jurisdictional claims in published maps and institutional affiliations.

Received: 20 September 2017 Accepted: 25 June 2018

Published online: 04 July 2018

\section{References}

1. Cameron JS. The nephrotic syndrome and its complications. Am J Kidney Dis. 1987 Sep;10(3):157-71.

2. Glassock RJ. Secondary minimal change disease. Nephrol Dial Transplant. 2003 Aug;18(Suppl 6):vi52-8

3. Canetta PA, Radhakrishnan J. The evidence-based approach to adult-onset idiopathic nephrotic syndrome. Front Pediatr. 2015 Sep 25;3:78.

4. Chartrand C, Leeflang MM, Minion J, Brewer T, Pai M. Accuracy of rapid influenza diagnostic tests: a meta-analysis. Ann Intern Med. 2012 Apr 3; 156(7):500-11

5. MacDonald NE, Wolfish N, McLaine P, Phipps P, Rossier E. Role of respiratory viruses in exacerbations of primary nephrotic syndrome. J Pediatr. 1986 Mar; 108(3):378-82.

6. Kim SR, Lee SB, Kim IY, Lee DW, Rhee H, Seong EY, et al. Relapse of minimal change disease following infection with the 2009 pandemic influenza (H1N1) virus. Clin Exp Nephrol. 2012 Apr;16(2):329-32.

7. Kielstein JT, Termuhlen L, Sohn J, Kliem V. Minimal change nephrotic syndrome in a 65-year-old patient following influenza vaccination. Clin Nephrol. 2000 Sep;54(3):246-8.

8. Ferrara P, Gatto A, Vitelli O, Liberatore P, Del Bufalo F, Bottaro G. Nephrotic syndrome following H1N1 influenza in a 3-year-old boy. Iran J Pediatr. 2012 Jun:22(2):265-8

9. Kanahara K, Yorioka N, Kumagai J, Amimoto D, Nishiki T, Ochiai M, et al. A case of nephrotic syndrome with rapid spontaneous remission in an elderly patient. Hiroshima J Med Sci. 1997 Sep;46(3):93-7.

10. Mori S, Matsushita Y, Arizono K. Minimal-change nephrotic syndrome associated with isoniazid in anti-tuberculosis chemoprophylaxis for a patient with rheumatoid arthritis. Intern Med. 2011;50(3):253-7.

11. Lin CY, Hsu HC. Histopathological and immunological studies in spontaneous remission of nephrotic syndrome after intercurrent measles infection. Nephron. 1986:42(2):110-5.

12. Saeed MB. Varicella-induced remission of steroid-resistant nephrotic syndrome in a child. Saudi J Kidney Dis Transpl. 2004 Oct-Dec:15(4):486-8

13. Kron MA, Hedger R. Hepatitis A-induced remission of minimal change nephropathy. Arch Intern Med. 1984 Nov;144(11):2279-80.

14. Zhang H, Wang Z, Dong L, Guo Y, Wu J, Zhai S. New insight into the pathogenesis of minimal change nephrotic syndrome: role of the persistence of respiratory tract virus in immune disorders. Autoimmun Rev. $2016 \mathrm{Jul} ; 15(7): 632-7$.

15. Ishimoto T, Shimada M, Araya CE, Huskey J, Garin EH, Johnson RJ. Minimal change disease: a CD80 podocytopathy? Semin Nephrol. 2011 Jul;31(4):320-5.

16. Mishra OP, Ibrahim N, Usha DBK. Serum immunoglobulin E in idiopathic nephrotic syndrome. J Trop Pediatr. 2004 Jun;50(3):149-52.

17. Raml A, Sedlak M, Schmekal B, Stuby U, Syre' G, Biesenbach G. Spontaneous remission of therapy-resistant minimal change nephritis in an adult woman 12 years after onset of the disease. Wien Med Wochenschr. 2006 Jul:156(13-14):421-5.

18. Nolasco F, Cameron JS, Heywood EF, Hicks J, Ogg C, Williams DG. Adultonset minimal change nephrotic syndrome: a long-term follow-up. Kidney Int. 1986 Jun;29(6):1215-23.

19. Shinzawa M, Yamamoto R, Nagasawa $Y$, Oseto S, Mori D, Tomida K, et al. Age and prediction of remission and relapse of proteinuria and corticosteroid-related adverse events in adult-onset minimal-change disease: a retrospective cohort study. Clin Exp Nephrol. 2013 Dec:17(6):839-47.

20. Mak SK, Short CD, Mallick NP. Long-term outcome of adult-onset minimalchange nephropathy. Nephrol Dial Transplant. 1996 Nov;11(11):2192-201.

21. Tse KC, Lam MF, Yip PS, Li FK, Choy BY, Lai KN, et al. Idiopathic minimal change nephrotic syndrome in older adults: steroid responsiveness and pattern of relapses. Nephrol Dial Transplant. 2003 Jul;18(7):1316-20.

\section{Ready to submit your research? Choose BMC and benefit from:}

- fast, convenient online submission

- thorough peer review by experienced researchers in your field

- rapid publication on acceptance

- support for research data, including large and complex data types

- gold Open Access which fosters wider collaboration and increased citations

- maximum visibility for your research: over $100 \mathrm{M}$ website views per year

At BMC, research is always in progress.

Learn more biomedcentral.com/submissions 